\title{
Working Hour Regulation and its Reform in Japan
}

\section{Introduction}

$\mathcal{7}($ orking hour regulations in Japan face two challenges: 1 ) how to reduce long working hours which hinder work-life balance, and sometimes cause "Karoshi $i^{1}$ (death from overworking)", and 2) how to modernize the traditional and obsolete regulations which do not necessarily fit to the contemporary working environment, especially that of white-collar workers.

\subsection{Has the Long Working Hours in Japan Gone?}

Average working hours actually worked in 1980 in Japan was 2108 hours but they were reduced to around 1800 now (see Figure 1). But the figure is average working hours of both full-time and part-time workers. Therefore the statistics do not necessarily reflect persistent long working hours of full-time, regular workers in Japan.

Japan has traditionally been well-known for its long working hours. There were several reasons for such long working hours. First, until the 1980s, the 5-day-workweek system did not permeate throughout small and medium sized enterprises. Second, overtime was incorporated into Japanese employment relations as a means to absorb business fluctuations without resorting to economic dismissals ${ }^{2}$. Third, there long has been

* Prof. of Labour Law. Faculty of Law. The University of Tokyo.

1 "Karoshi" can be translated broadly as death that occurs as a result of excessive work (involving such things as extremely long working hours or unnaturally high stress levels). More narrowly, it is defined as death caused by cerebrovascular disease or ischemic heart disease (e.g. cerebral infarction, subarachnoid hemorrhage, myocardial infarction, angina) resulting from excessive work. See: JILPT [The Japan Institute for Labour Policy and Training], Labor Situation in Japan and Its Analysis: General Overview 2013/2014, 104.

${ }^{2}$ In the economic downturn, the Japanese employers often stopped ordering overtime instead of resorting to economic dismissals in order to reduce labor cost. 
a low utilization of annual paid leaves. To reduce long working hours, to cope with changes in industrial structure, and also to mitigate international criticism at social dumping, the provisions concerning working hours and annual leaves in the Labor Standards Act (hereinafter "LSA") were drastically revised in 1987, to reduce the legal workweek from 48 to 40 hours. Subsequently, working hours regulations in the LSA were revised in 1998, 2003 and 2008 to accommodate socio-economic changes.

Figure 1. Averaged Annual Hours worked per Worker

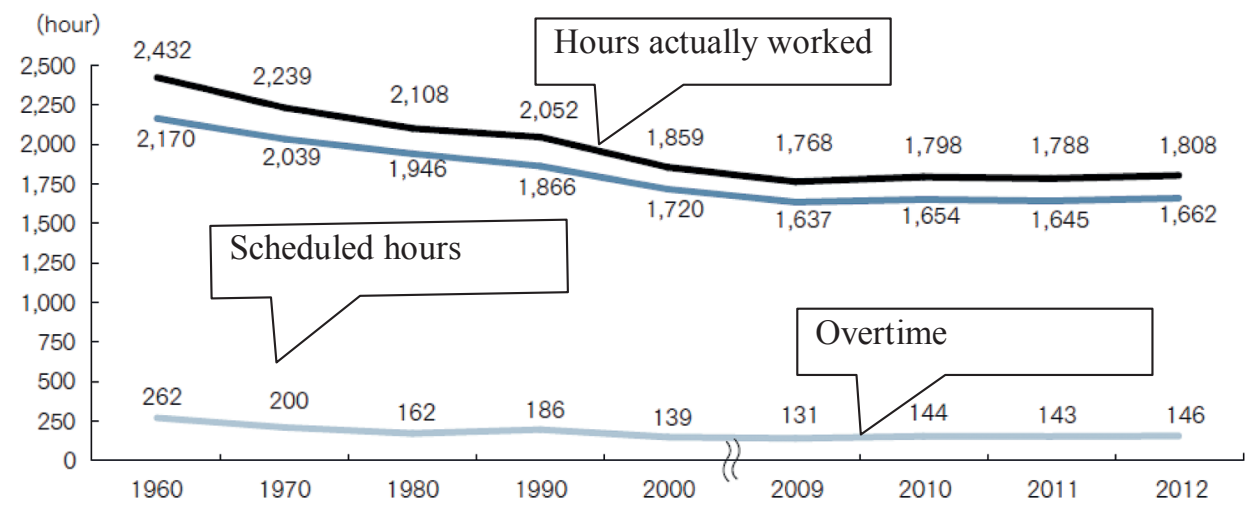

Japan Institute for Labor Policy and Training, Japanese Working Life Profile 2014, 56 (JILPT, 2014)

The revision of the LSA and government's vigorous campaign to lessen the number of hours worked ostensibly has led to their conspicuous reduction. According to the statistics of OECD, average annual hours actually worked per worker (dependent person) in Japan is 1765 in 2012, which is shorter than the figure in the US (1797 hours).

However, two supplementary comments should be added. First, when compared with European countries, working hours in Japan are still 300-400 hours longer than in France (1402 hours) and in Germany (1316 hours) $)^{3}$. Second, the above-mentioned 1765 hours is the average number of working hours of both regular (full-time) workers and part-time workers. Because of the increase in part-time workers in Japan, average working hours have decreased, even though the regular workers' annual working hours have remained over 2000 hours in the last two decades (See Figure 2). Therefore, reducing working hours remains an important labor policy issues in Japan.

${ }^{3}$ OECD Database, Average annual hours actually worked per worker. https://stats. oecd.org/Index.aspx?DataSetCode=ANHRS. 
Figure 2. Annual Total of Hours Actually Worked by Regular and Part-time Workers

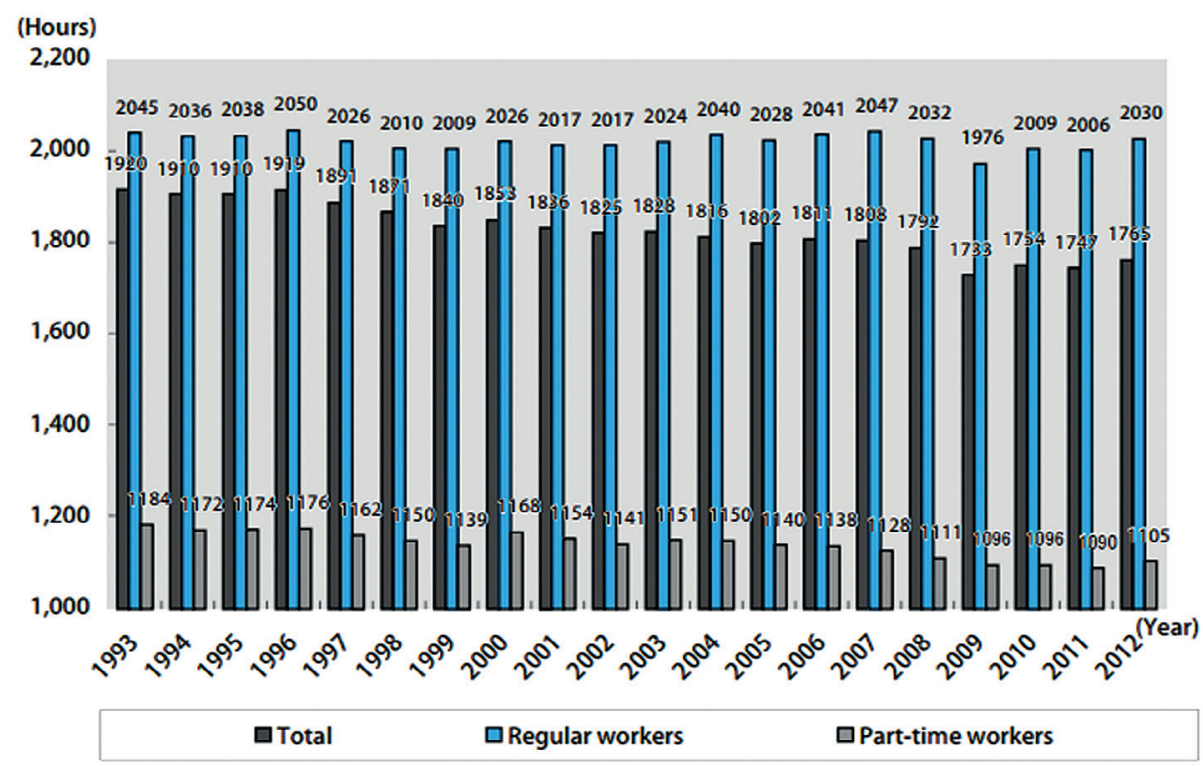

JILPT, Labor Situation in Japan and Its Analysis: General Overview 2013/2014, 101

\subsection{Modernized Working Hour Regulation of White-collar Workers and/or Exemption?}

Since more than half of the Japanese workers are white-collar and traditional work hour regulations needed modernization. Since 1987 revision of the LSA, Japan has introduced various flexible work hour system including hours averaging system, flex-time, and so-called "discretionary work schemes".

In the mid 2000s, white-collar exemption surfaced one of the most debated labor policy issues in Japan. For the proponents, current work hour regulations requiring overtime payment to most white-collar workers have given them incentive to work slowly during scheduled hours and earn more overtime premium, and eventually have led to the lower productivity and creativity of the Japanese corporations. For the opponents, white-collar exemption not only deprives them of their rights of overtime payments but also accelerates Karoshi problem.

This article overviews developments of working hour regulations in Japan to reduce working hours, and examines current discussion concerning special regulations of working hours for white-collar workers. 


\section{Principles of Regulations on Working Hours, Rest Periods and Rest Days}

Comparatively speaking, there are two types of working hours regulations. One directly prohibits working hours exceeding maximum limits which is enforced by criminal and administrative sanctions, an approach that is often adopted by European countries. The other places no legal limits on the number of working hours, but simply requires payment of overtime premium for hours exceeding a legally-defined standard number of workweek hours, as adopted in the US Fair Labor Standards Act.

Japanese working hours regulations take the approach of the European style regulations. The LSA prohibits working hours exceeding maximum limits (a 40 hour workweek and 8 hour workday). Violations are sanctioned not only by mandatory civil norms, but also by criminal provisions. However, exceptions of maximum working hours is allowed by the conclusion of a majority representative agreement in a more relaxed manner than in European countries as explained later (3.2).

\subsection{Forty-hour workweek system}

The LSA of 1947 adopted an 8-hour workday and a 48-hour workweek system, and it was maintained until its large-scale revision in 1987. The revised LSA introduced a 40-hour workweek and 8-hour workday system (LSA, Art. 324). This aimed to set a 5-day workweek standard. The Act incorporated several stages by which the goal of 40-hours workweek was to be attained. Namely, a 46 hour workweek was introduced in 1988, a 44 hour work week in 1991, and from April 1, 1994, a 40 hour workweek was put into effect. For small and medium sized enterprises and certain occupations, however, the Act allowed a 44-hour workweek by way of deferment. It was from April 1, 1997 that the 40-hour workweek was completely put into effect except for extremely small businesses in the service industry ${ }^{5}$.

\subsection{Rest Periods}

The LSA provides that an employer must provide rest periods of a minimum of 45 minutes during working hours which exceed six hours, and rest periods of at least one hour if working hours exceed eight hours (LSA,

${ }^{4}$ LSA, Art. 32 (1) An employer shall not have a worker work more than 40 hours per week, excluding rest periods. (2) An employer shall not have a worker work more than 8 hours per day for each day of the week, excluding rest periods.

${ }^{5}$ For shops, movie and theatrical enterprises, sanitation enterprises, and entertainment and recreation enterprises that normally employ fewer than ten workers, 44-hour workweek is allowed as exceptions to the principle regulations (LSA Art. 40; LSAEO Art. 25-2). 
Art. 34 Pare. 1). Rest periods must be provided to all workers at the same time, unless the employer concludes written agreement with the majority representative of workers in the establishment which provides otherwise (LSA, Art. 34 Para. 2). An employer must permit free use of rest periods (LSA, Art. 34 Para. 3). Stand-by time [Temachi-jikan] during which a worker is required to stay on duty is interpreted as working time.

Japanese law has not regulated the daily rest or the interval between the end of a workday and the beginning of the next workday.

\subsection{Weekly Rest Days}

An employer must provide workers with at least one rest day per week (LSA, Art. 35 Para. 1). Because of the lack of religious influences, a weekly rest day need not be on a specific day such as Sunday. Furthermore if an employer provides four rest days during a four week period, he or she need not provide one rest day for each week (LSA, Art. 35 Para. 2).

Though the Act requires one rest day per week, since the regulation of the 40-hour workweek and 8-hour workday anticipates a 5-day workweek, the majority of Japanese workers are already subject to a 5-day workweek.

National holidays, which amount to 15 days $^{6}$ a year, are not regarded as mandatory rest days under the LSA. Accordingly, an employer has no duty to provide a day-off on national holidays. In practice, however, most companies are closed on such days.

\subsection{Exemptions from the Principle Regulations}

The legal principle of maximum working hours, rest periods, and rest days does not apply to the following:

1 ) those working in agriculture, animal husbandry and fishing (LSA, Art. 41 No 1);

2) those in positions of supervision or management or those handling confidential matters, regardless of the type of enterprise (LSA, Art. 41 No 2); and

3) those engaged in keeping watch or in intermittent labor under the condition that the employer has obtained permission from the Labor Standards Inspection Office (LSA, Art. 41 No 3).

Consequently, all the working hours regulations including overtime pay regulations do not apply to these workers. Recently, many cases alleging misclassification of workers as being in the position of supervision or management were filed and attracted attention (see 5.1).

${ }^{6}$ From 2016, it will be 16 days by the addition of the Day of Mountain (August 11). 


\section{Regulations of Overtime, Rest-day Work and Night Work}

Overtime and rest-day work are exceptions to the above-mentioned regulations. They are allowed under two circumstances: in cases of emergency, and when a majority-representative agreement is concluded and so provides. Here "overtime" and "rest-day work" means hours worked over maximum working hours, and work on legally required weekly rest days under the LSA. Therefore the regulations discussed below, including those concerning overtime payments, are not applied to hours exceeding the scheduled working hours but not exceeding legal maximum hours ${ }^{7}$.

\subsection{Emergencies}

According to Art. 33 of LSA, in the event of temporary necessity by reason of disaster or other unavoidable circumstances, an employer, with permission of the Labor Standards Inspection Office, may extend maximum working hours and may have workers work on rest days. When the necessity is so urgent that there is not enough time to obtain administrative permission, the employer must report this after the fact without delay. When the Labor Standards Inspection Office determines that the overtime or rest-day work was inappropriate, the Office may order the employer to provide the workers with rest periods or rest days corresponding to the overtime.

Permission for emergency work can be obtained only in urgent situations. According to administrative interpretations, a claim of mere business fluctuations or regular maintenance or repair of facilities is insufficient to obtain permission.

\subsection{Majority-Representative Agreement for Overtime or Rest-day work}

When an employer concludes an agreement with majority-representative, namely a union organizing a majority of the workers in the establishment or with a person representing a majority of the workers where no such union exists ${ }^{8}$, and submits it to the Labor Standards Inspection Of-

${ }^{7}$ For example, the eighth hour worked when scheduled working hours is seven hours per day is not subject to the LSA regulations on overtime payments. However, courts normally interpret that parties explicitly or Implicitly agree to pay overtime premium for hours exceeding scheduled hours in the same way as for hours exceeding legal maximum hours.

${ }^{8}$ Under the revision of the LSA, when a worker-management committee (Art. 38-4 Para 1) is established, the unanimous resolution of such committee replaces the worker-management agreement. 
fice, the employer may exceed maximum working hours and have workers work on rest days (LSA Art. 36). This conclusion of a majority-representative agreement (often called a "36 Agreement") provides the primary mechanism allowing for the performance of overtime or rest-day work.

Unlike regulations in European countries, the LSA has set no limitation on the amount of overtime, except for the two-hours per day limitation for underground work and other hazardous work specified by an ordinance of the Ministry of Labor (LSA Art. 36 Para 1 Proviso, LSAEO Art. 18).

Table 1. Standards on overtime limitation

\begin{tabular}{|c|c|}
\hline $\begin{array}{c}\text { Unit period for overtime specified } \\
\text { by the parties }\end{array}$ & Maximum overtime hours \\
\hline 1 week & 15 hours \\
\hline 2 weeks & 27 hours \\
\hline 4 weeks & 43 hours \\
\hline 1 month & 45 hours \\
\hline 2 months & 81 hours \\
\hline 3 months & 120 hours \\
\hline 1 year & 360 hours \\
\hline
\end{tabular}

From 1982 and until the introduction of the explicit provision concerning the standards on overtime limitation, administrative guidance had set the standards for the maximum hours. This standard was no more than a guideline calling for voluntary compliance. In practice, however, the standard functioned as a de facto binding limitation on overtime. The 1998 LSA revision gave this administrative guidance more solid legal ground by providing that the Minister of Labor (currently the Minister of Health, Labor and Welfare) can set standards for the limitation of overtime (LSA Art. 36 Para. 2). On the basis of this provision, the contents of the previous guideline were converted into a Ministry Ordinance concerning standards on overtime limitation (see Table 1).

\subsection{The Duty of Overtime and Rest-day Work}

The conclusion and filing of a 36 Agreement exempts an employer from violation of maximum working hours or weekly rest day regulations. However, it does not establish the workers' duty to perform overtime or rest-day work, because a 36 agreement is neither a collective bargaining agreement nor an agreement with a binding effect on individual labor contracts. To order overtime, an employer needs to incorporate the duty to perform overtime in contracts through collective bargaining agreements, work rules or individual labor contracts. Though some contend 
that an employer must acquire a worker's individual consent each time to order overtime, the Supreme Court has not supported such an interpretation. Instead, the Court held that a provision in work rules stipulating that workers were subject to overtime orders based upon business necessity were sufficient ${ }^{9}$.

\subsection{Premium Payment for Overtime, Rest-day work and Night Work}

When an employer orders overtime pursuant to Art. 33 (emergency work) or an Art. 36 agreement, he is required to pay an overtime premium of not less than $25 \%$ of the worker's normal wages per working hour. When the number of overtime per month exceeds 60 hours, the premium rate is raised to $50 \%{ }^{10}$ (LSA Art. 37, Para. 1). By the established case law $^{11}$, an employer who orders illegal overtime, such as overtime without the conclusion of a majority-representative agreement, also bears the duty to pay the overtime premium.

As for rest-day work, an employer must pay at a rate of at least 35\% over the worker's normal wages.

Night work from 10:00 p.m. to 5:00 a.m. requires a premium payment 662 of $25 \%$ of the workers' normal wages. Where overtime overlaps with night work, a $50 \%$ premium is required. Where rest-day work and night work overlaps, a $60 \%$ premium is required.

In calculating the overtime premium, family allowances, commuting allowances and other wages designated by the Ordinance, namely allowances for separation from one's own family, education allowances for employees' children, accommodation allowances, wages irregularly paid, and wages regularly paid over the period longer than one month, can be excluded (LSA Art. 37 Para. 5, LSAEO Art. 21).

\section{Flexible Work Hour System}

The 1987 LSA revision introduces several forms of flexible work hour systems: three working hours-averaging schemes over a certain period and a so-called "flex-time system".

The introduction of these flexible work hour schemes has two goals: to cope with the changes in industrial structure and types of work, such

9 The Hitachi Ltd. case, Supreme Court (Nov. 28, 1991), 45 Minshu 1270.

${ }^{10}$ For the time being, the small and medium sized enterprises (such as those employ 300 and less workers) are exempted (LSA Art. 138).

11 The Kojima Nenshi case, Supreme Court (Jul. 14, 1960), 14 Keishu 1139. 
as an increase in service industries and white-collar jobs, and to reduce the number of working hours through their flexible distribution. Some provisions of these hours-averaging schemes were further revised by the 1998 LSA revision.

\subsection{Hours-averaging scheme over a one-month period}

The hours-averaging scheme over a one-month period is a slightly modified system of a previous averaging scheme over a period of four weeks, which was the only averaging scheme until the 1987 revision of the LSA. The averaging period was prolonged from four weeks to one month because wages are normally calculated not a weekly but a monthly basis (LSA Art. 32-2). In order to utilize this system, an employer must so provide in the work rules or conclude a majority-representative agreement at the establishment and submit it to a labor inspection office. The work rules or majority-representative agreement must indicate the unit period shorter than one month, during which working hours are averaged within the framework of maximum hours, and must specify the daily and weekly scheduled hours. In businesses where such specification of scheduled hours is difficult, such as business in the transport industries, a relaxed specification is allowed through specifying one of several work schedules prescribed in the work rules. Then, the employer may choose one from among these schedules. According to the administrative interpretation, such a system is also legal under the one-month hours-averaging scheme ${ }^{12}$.

Under these schemes, prescribed hours exceeding maximum daily or weekly working hours are not treated as overtime if the average number of scheduled working hours do not exceed the maximum in the framework of the averaging unit period. The maximum framework within a specified averaging unit is calculated by the formula: 40n/7 ( $\mathrm{n}=$ days in the unit period). Therefore if the unit period is 31 days, the total number of maximum working hours is 177.1 hours $(40 \times 31 / 7=177.1)$. There is no limit to a daily or weekly distribution of hours.

Since exceeding the daily $(8 \mathrm{~h})$ or weekly $(40 \mathrm{~h})$ maximum is allowed on the condition that the daily or weekly hours are scheduled in advance in either work rules or majority-representative agreement, hours exceeding scheduled hours and at the same time exceeding maximum hours become illegal overtime work even if total hours worked within the unit period do not exceed the maximum framework. For instance, suppose the Monday to Friday work schedule calls for the following hours: 10, 10, $6,6,6$. If a worker works 11 hours on Monday, the $11^{\text {th }}$ hours is regarded

${ }^{12}$ Notice by the Director of the Labor Standards Division, No 150, March 14, 1987. 
as illegal overtime even though the worker works less than total 40 workweek because the $11^{\text {th }}$ hour on Monday which exceeds daily (8h) maximum is not scheduled in advance in the averaging scheme.

\subsection{Hours-averaging scheme over a one-year period}

The 1987 revision of the LSA introduced a hours-averaging scheme over a three-month period. The 1993 amendment of the Law extends the averaging period to one year. Under the requirements explained hereinafter, specified working hours exceeding maximum daily or weekly hours are not regarded as overtime. This scheme is designed to reduce working hours in service industries such as department stores which have considerable seasonal fluctuations in business.

To introduce this averaging scheme, an employer must conclude an agreement with a majority representative at the establishment. In the agreement, the following must be prescribed: (i) a clarification of covered workers; (ii) a unit period less than one year over which hours are averaged; and (iii) a valid term of the agreement (LSA Art. 32-4 Para. 1; LSAEO Art. 12-4 Para. 1).

In addition, the majority-representative agreement (or Labor-Manage664 ment Agreement) must specify scheduled hours which may not exceed the maximum hours framework, or 40 hours per week on average during the unit period. When the parties to the agreement choose to divide several unit periods of not less than one month each, advance specification of working hours in all workdays is required only for the first unit. However, scheduled hours in the following units must be specified at least thirty days before the beginning of each unit by a majority-representative agreement (LSA Art. 32-4 Para. 2). Furthermore, a distribution of hours is subject to a 10-hour per day ceiling and 52-hour per week ceiling and one rest day must be ensured at least every six workdays (LSAEO Art. 12-4 Para. 4,5 ). A scheduled workweek more than 48 (and fewer than 52) hours per week must not continue for more than three weeks and there must be no more than three of such workweeks within a period of three months.

Finally, the majority-representative agreement must be submitted to the Labor Standards Inspection Office (LSA Art. 32-4 Para. 4).

\subsection{Hours-averaging scheme over a one-week period}

This one-week hours averaging scheme is called an "irregular hours distribution system" because it does not require advance specification of scheduled daily or weekly hours. This scheme is, however, only available to undertakings recognized by administrative order as businesses 
subject to wide day-to-day fluctuations and which therefore have difficulties specifying daily working hours in the work rules and whose number of workers is below the designated standard (LSA Art. 32-5). Under current regulations, retail businesses, hotels, restaurants, and snack bars that normally employ fewer than 30 workers are so designated (LSAEO Art. 12-5).

To utilize this scheme, an employer must conclude an agreement with a majority representative at an establishment and submit it to the Labor Standards Inspection Office.

Under this scheme, an employer need not specify the working hours on each day in the work rules or majority-representative agreement. Instead, he is required to notify the workers of the scheduled hours of each day, in writing, by the beginning of each week. However, when urgent and unavoidable grounds exist, an employer can change the notified hours by the day before the day in question (LSAEO Art. 12-5 Para. 3). Hours distributed in a week are subject to a 10-hour ceiling (LSA Art. 32-5 Para. 1).

\subsection{Flex-time}

A "flex-time" or variable working time system is one in which workers can choose the start and end of their daily working hours as they wish as long as they work the designated number of hours for a certain unit period. A flex-time system resembles hours-averaging schemes in that exceeding daily or weekly maximum working hours is not regarded as overtime under the LSA as long as the average weekly hours during a unit period ("settlement period [seisan kikan]") are within the weekly maximum working hours. Hours-averaging schemes, however, allow maximum hours to be exceeded only on specified days in the work rules or in a majority-representative agreement, whereas a flex-time system does not require such specification of daily working hours and concerns only total hours worked within a settlement period.

The first requirement for a flex-time system is that the work rules give workers covered by the system a choice of time for starting and ending work. It is possible for an employer to set forth a "core time" in which workers must be present. However, in a "flexible-time period", during which workers can decide their starting and ending work time, the employer cannot order the workers to report by a certain time or to remain until a certain time without the workers' consent.

The second requirement is a majority-representative agreement setting forth the following: 1) the scope of the workers covered by the flextime system, 2) a settlement period not in excess of one month, in which 
hours are averaged, 3) the "total working hours" which workers are obliged to work in the settlement period, 4) the standard hours of daily work, 5) a "core-time" when such periods are provided in the agreement, and 6) the starting and ending time of a "flexible-time" when the parties want to limit such periods (LSA Art. 32-3; LSAEO Art. 12-3).

Though a majority-representative agreement concerning a flex-time system permits an employer to calculate working hours by averaging in a settlement period, it is understood that it does not have a direct effect on individual employment contracts. To enforce the system, therefore, the employer needs detailed provisions in the work rules or individual contracts with workers.

\section{Work Hour Regulation Reform for White-Collar Workers: White-Collar Exemption and Discretionary Work Scheme}

\subsection{Traditional White-collar Exemption}

As mentioned above, LSA has traditionally had exemption for those in positions of supervision or management or those handling confidential matters, regardless of the type of enterprise since 1947 (LSA Art. 41 No 2). When a worker is deemed as being the exempted supervisory or managerial worker, all the working hours regulations, namely maximum working hours, rest periods, rest days as well as overtime pay regulations, do not apply to these workers.

The problem of the traditional exemption system is in that there is no substantive regulations such as functional requirement and minimum remuneration to be regarded as being a supervisory or managerial worker, nor procedural requirements such as collective/individual agreement of exemption and permission by the administrative agencies. All is entrusted to the interpretation whether the person is in the position of supervision or management.

Of course, The Ministry of Health, Labor and Welfare and the courts have restrictively interpreted this exemption because it is the exception to the fundamental regulations on work hours. However, many cases have been reported that employers abusively misclassified ordinary workers as being exempt.

Among many misclassification cases, the most widely covered by media was the McDonald's case in which the shop manager directly hired by McDonald's Japan worked overtime from 18 to 105 hours per month in two 
years from December 2013 through November 2015, but was not paid any overtime premium because he was treated as an exempt managerial worker. The Tokyo district Court held that the shop manager was not in the similar position to the employer to engage in managerial decision making, lacked discretion concerning working time, and was not sufficiently remunerated to be treated as an exempt, and thus the employer should pay him the undue overtime premium (about five million yen in total).

After the McDonald's case, the Ministry of Health, Labor and Welfare issued a new circular to prevent abusive misclassification to evade working hours regulations. At the same time, the limitation of the current exemption regulation was recognized and a discussion concerning the new white-collar exemption has started as seen below (5.3).

\subsection{Discretionary Work Scheme}

Apart from the exemption, Japan has introduced a unique work hour regulation concerning white-collar workers who engage in discretionary work since 1987.

When work hour regulations were initially established in 1947, workers covered by the LSA were mostly factory blue-collar workers. At that time, the universal application of rigid work hour regulations in general did not cause serious problems. However, it was believed to be unreasonable to apply normal working hours regulations to those workers who engaged in creative and discretionary activities, because such workers were free from their employer's direction with regard to the manner of their performance and the nature of their work requires that the work performed be evaluated on the basis of results rather than by the amount of time spent. With the increase in the number of such white-collar workers, application of overtime regulations have become especially problematic. For example, an efficient white-collar worker who completed his/her task within the scheduled work hours is paid less than an inefficient worker who was only able to finish his task by doing overtime, since the LSA mandates payment of an overtime premium (25\%) in accordance with overtime worked. Such regulations were incentive for workers to work less efficiently to receive the overtime premium. This explains one reason for Japan's long working hours and the lower productivity of white-collar workers as well.

The 1987 revision of the LSA, therefore, introduced "discretionary work scheme [sairyo rodo sei]" for workers who engage in professional type work such as research and development ("professional type" discretionary work scheme), and the 1998 LSA revision added a new discretionary work scheme for high-level white-collar workers ("management planning type" discretionary work scheme). 
Under the discretionary work scheme, hours worked is not calculated by the numbers actually worked but by "conclusive presumption [minasi]" of the number of working hours. This means that irrespective of hours actually worked, the employer can presume working hours conclusively as the number of hours fixed by the majority-representative agreement or work rules ${ }^{13}$.

The conclusive presumption schemes resemble an exemption in that employers need not to pay overtime payment in accordance with the hours actually worked. However, they differ in that when the stipulated hours for conclusive presumption exceeds maximum hours ( 8 hours a day, 40 hours a week), the so-called 36 agreement must be concluded and overtime payment should be paid.

\subsubsection{Discretionary Work Scheme (Professional Work Type)}

The discretionary work scheme (professional work type) was first introduced by the 1987 LSA revision ${ }^{14}$. This scheme allows an employer to calculate the number of work hours based on the conclusive presumption of hours worked that were agreed upon between the employer and the representative of workers irrespective of hours that were actually worked. For example, if a written agreement stipulates the conclusively presumed hours as 8 hours, the employer can deem a worker's working hours as 8 hours even if the worker actually worked 10 hours.

Regulators have grappled with the difficult issue of determining the scope of discretionary activities and have arrived at a more narrow, less flexible scheme which delineates specific duties, rather than allowing the parties to make the determination themselves in accordance

${ }^{13}$ Apart from the discretionary work scheme, the LSA has another conclusive presumption system for work performed outside the workplace (LSA, Art. 38-2). The number of hours worked outside the workplace or establishment is difficult for employers to measure. The 1987 LSA revision, therefore, introduced three ways of conclusive presumption of the number of working hours for outside work on the condition that those hours are difficult to calculate. The first conclusive presumption is that working hours outside the workplace are deemed scheduled work hours at the workplace (LSA Art. 38-2 par. 1). A second method of calculation is to presume that a worker worked the number of hours usually required to accomplish the duties when it would usually be required to work in excess of the scheduled hours (LSA Art. 38-2 Para. 1 Proviso). It is, however, difficult to determine the "hours usually required to accomplish the duties". Therefore the Act provides a third conclusive presumption. When there is a majority-representative agreement, the number of hours specified in such agreement shall be regarded as the number of hours required to accomplish the duties (LSA Art. 38-2 Para. 2). The agreement must be submitted to the Labor Standards Inspection Office (LSA Art. 38-2 Para. 3).

${ }^{14}$ T. Araki, Regulation of Working Hours for White-collar Workers Engaging in 'Discretionary Activities', “Japan Labor Bulletin” 1996, vol. 35-7, No 4. 
with the specific circumstances at hand. Under the 1987 LSA revision, the scope of discretionary duties could be determined by the employer and a majority representative. However, faced with the labor's criticism against abusive applications of the scheme, the 1993 amendment limited the availability of this scheme to the five designated duties (No 1-5 in the current regulation explained below). Though six duties (No 6-11 explained below) were added to the list in 1997, employers claimed that such an exhaustive list regulation was too rigid. This was one reason requiring for another type (management planning type) discretionary work scheme.

Currently the Law limits the availability of this scheme to the following 11 designated duties:

1) research and development of new products and technology;

2) planning and analysis of information-management systems;

3) gathering of information and editing in the mass media;

4) designing;

5) producing and directing TV or movie productions;

6) copy-writing;

7) public accounting;

8) lawyering;

9) duties of first-grade architects;

10) duties of real estate appraisers; and

11) duties of patent agents (LSA Enforcement Ordinance, Art. 24-2-2 Para. 6; Notification No 7 of Ministry of Labor, February 14, 1997).

To utilize the scheme, the employer is required to conclude a written agreement with a majority representative at the establishment. In the agreement, the parties to the agreement are required to specify the activities covered by the system, to prescribe that the employer shall not give any direction concerning the means of performing the tasks and allocation of working hours, and to prescribe that the number of hours worked by those workers covered by the scheme shall be regarded as the number of hours fixed in the agreement. Such an agreement must be submitted to the Labor Standards Inspection Office (LSA, Art. 38-3).

\subsubsection{Discretionary Work Scheme (Management Planning Type)}

The limited availability of the professional work type discretionary work scheme, and the development of performance-based wage systems requiring exemption from normal working hours regulations, caused business circles to argue for expansion of discretionary work schemes to include workers engaging in planning of business strategy, sales, finance, public relations and so forth. After heated debates and exceptional amendments in the Diet, the 1998 LSA revision introduced a new discretionary 
work scheme for high-level white-collar workers ("management planning type" discretionary work scheme) (LSA, Art. 38-4) $)^{15}$.

The 2003 LSA revision slightly relaxed the prerequisites for utilizing this scheme. Under the current law, they are as follows: First, the worker's duties must be "duties of planning, investigation and analysis on matters regarding management of enterprise", and "for their proper implementation the nature of such duties requires that the means of accomplishment must be mostly entrusted to the discretion of workers, and no concrete direction will be given regarding the means of performance as well as the allocation of time" (LSA, Art. 38-4, Para. 1 No 1). Unlike the "professional work type" discretionary work scheme, this scheme does not exhaustively list available duties. Instead this scheme entrusts the determination of the available duties to the labor-management committee.

Second, the Act requires that workers "must have knowledge and experience of performing such duties properly" (LSA, Art. 38-4, Para. 1 No 2). According to administrative guidance, at least three to five years of experience on such duties is an important factor to be considered in determining whether the management planning type scheme is available.

Third, the Act prescribes the following procedural requirements.

1) Establishment of a "labor-management committee [Roshi Iinkai]" is required. The labor-management committee is a body consisting of both labor and management representatives. Half of the committee members must be worker representatives appointed for a specific period by the labor union organized by the majority of workers at the establishment or by the person representing the majority of workers where no such union exists.

2) The labor-management committee must by four-fifths majority of the committee members determine duties and workers covered by this scheme, the number of hours that will be conclusively presumed, the employer's measures to ensure health and welfare of workers covered by the scheme, and the employer's measures to process grievances of such workers (LSA, Art. 38-4 Para. 1 No 1-5). The committee must further by four-fifths' majority resolve that application of the scheme must be based on an individual worker's consent and that disadvantageous treatment of workers who do not give consent is prohibited (LSA, Art. 38-4 Para. 1 No 6).

3) The resolution of the labor-management committee must be submitted to the Labor Standards Inspection Office.

The notable features of the management planning type discretionary work scheme is its reliance on procedural regulation and on workplace level autonomy. Instead of regulating the actual duties subject to the Act's

${ }^{15}$ R. Yamakawa, Overhaul After 50 Years: The Amendment of the Labour Standards Law, “Japan Labor Bulletin" 1998, vol. 37-11, No 9. 
scheme, it requires the establishment of labor-management committees, four-fifths' majority resolutions, and the consent of the individual worker. However, partly because of the strictness of prerequisites and procedures, the schemes have not been widely adopted.

\subsection{Proposal of New White-Collar Exemption}

Current white-collar exemption prescribed in LSA Art. 41 No 2 has various problems as mentioned earlier: its narrow scope interpreted by the administration and courts, and abusive misclassification in practice because of the lack of the substantive and procedural regulations. In order to cope with the increase in white-collar workers who are given wider discretion in performance of their work, discretionary work schemes were introduced. However, because of the strict substantive and procedural regulations, they are not widely adopted. According to the survey in 2013, the professional type discretionary work scheme was applied to only $1.2 \%$ of all workers, and the management planning type one was applied to $0.3 \%$ of them ${ }^{16}$.

Considering these situations, the Japanese government proposed to introduce a new white-collar exemption. The new proposal called "high-level professional scheme" plans to introduce both substantial and procedural regulations.

The workers who can be subject to the new exemption are those who are engaged in the duty that requires high-level expertise, technique or experience and that there is not strong relationship between his/her performance and hours worked. The duty of the worker subject to the new exemption scheme should be clearly agreed between the employer and the worker in writing. The worker's yearly remuneration should be higher than 10.75 million yen (details should be prescribed in the Enforcement Ordinance).

Responding to the criticism that the new exemption accelerates Karoshi problem, the proposal introduces various measures to ensure worker's health protection. First, the employer must measure the number of hours that the applied worker stays in the office (including rest period and idle time) and he/she engages in work outside of the office ("hours for health management"), and must apply necessary measures to secure worker's health based on hours for health management. The scheme gives three options for the necessary measure based on the hours for health management:

1) to give certain time of daily rest within 24 hours and set the maximum number of night work (details should be prescribed in the Enforcement Ordinance);

${ }^{16}$ Ministry of Health, Labor and Welfare, Heisei 25 nen Shuro Joken Sogo Chosa (2013 General Survey on Employment Conditions). http://www.mhlw.go.jp/toukei/itiran/ roudou/jikan/syurou/13/gaiyou01.html. 
2) to limit the maximum hours for health management in a month or three months (details should be prescribed in the Enforcement Ordinance); and

3) to give more than four rest days per four weeks and more than 104 rest days in a year. The labor-management committee shall adopt one of these three options. An employer is obliged to ensure medical examination for the worker whose hours for health management exceeds certain number.

As to the procedural regulations, under the proposed scheme, the worker's individual agreement is indispensable. In other words, individual workers are free to opt out from the new scheme. Unfavorable treatment for their refusal is prohibited. On top of individual agreement, resolution by four-fifths' majority of the members in the labor-management committee is required concerning the following matters:

1) scope of applicable duties;

2) scope of applicable workers;

3) employer's obligation to measure hours for health management and the methods;

4) implementation of measure based on hours for health management;

5) implementation of dispute resolution;

6) prohibition of unfavorable treatment of the worker who does not give an agreement to be subject to the scheme.

The employer is also required to report to the administration the situation of measures taken for the health management in six months after implementing them.

The bill to introduce the new white-collar exemption was submitted by the cabinet in March 2015 to the Diet.

\section{Conclusion}

This chapter overviewed the developments of the Japanese work hour regulations. To reduce notorious long working hours, Japan changed the maximum work week from 48 to 40 , introduced various flexible work hour systems, and also introduced unique discretionary work scheme for white-collar workers. Average working hours actually worked had certainly decreased in the last three decades but the main factor of this trend was the increase in the number of part-time workers. Long working hours among the regular full-time workers remains persistently in Japan.

The Japanese law also faces challenges to adapt work hour regulations to changing work environment with increasing white-collar workers with wider discretion in performing their work. Many employers abusively misclassified those white-collar workers into exempt category, but courts 
have regarded such employers' treatment as evasion of the mandatory work hour regulations. The misclassification was partly induced by the insufficient regulation of the traditional exemption provision which lacks both substantive and procedural proper regulations. Considering such experience, the government has currently proposed a new white-collar exemption scheme with detailed substantive and procedural requirements.

Long working hours of regular workers cause low productivity of the Japanese white-collar workers. They also hinder work-life balance and career development of able female workers. To reduce long working hours of male full-time workers is indispensable to attain equal employment for both sex as well. Therefore, the proposed work hour reform should lead not only to the modernization of the work hour regulations but also to reconsideration of the traditional work pattern rooted in the Japanese society.

\section{Bibliography}

Araki T., Regulation of Working Hours for White-collar Workers Engaging in 'Discretionary Activities', “Japan Labor Bulletin” 1996, vol. 35-7, No 4.

JILPT [The Japan Institute for Labour Policy and Training], Labor Situation in Japan and Its Analysis: General Overview 2013/2014.

Ministry of Health, Labor and Welfare, Heisei 25 nen Shuro Joken Sogo Chosa (2013 General Survey on Employment Conditions).

Yamakawa R., Overhaul After 50 Years: The Amendment of the Labour Standards Law, "Japan Labor Bulletin" 1998, vol. 37-11, No 9.

\section{Regulacja czasu pracy i jej reforma w Japonii}

\section{Streszczenie}

Regulacja czasu pracy w Japonii napotyka dwa wyzwania: długie godziny pracy i przestarzałe regulacje, niedostosowane do rosnącej liczby pracowników umysłowych (white-collar workers). Niniejszy tekst ukazuje ewolucję regulacji czasu pracy w kierunku skrócenia maksymalnych norm z 48 do 40 godzin i wprowadzenia różnych elastycznych systemów czasu pracy. Pomimo że przeciętny czas pracy zmniejszył się w ciągu ostatnich trzech dekad, jego długość w odniesieniu do pracowników umysłowych wciąż pozostaje $\mathrm{w}$ Japonii problemem socjalnym.

Długi czas pracy powoduje niską produktywność pracowników umysłowych, utrudnia zbalansowanie pracy i życia oraz równe zatrudnienie obydwu płci. Rząd przedłożył projekt reformy czasu pracy w 2015 r. Powinna ona prowadzić nie tylko do modernizacji unormowań czasu pracy, lecz także do rewizji tradycyjnego modelu pracy zakorzenionego w japońskim społeczeństwie. 